\title{
LONG-TERM POSTOPERATIVE ENDOSCOPIC FINDINGS AFTER GASTRIC BYPASS PROCEDURE: a co-occurrence analysis
}

\author{
Luiz Gustavo de QUADROS ${ }^{1,2}$, Roberto Luiz KAISER JUNIOR ${ }^{1}$, \\ Manoel dos Passos GALVÃO NETO ${ }^{2,3}$, Josemberg Marins CAMPOS ${ }^{2,4}$, \\ Marcelo Falcão de SANTANA ${ }^{2,4}$ and Alvaro Antonio Bandeira FERRAZ ${ }^{4}$
}

Received 27/4/2016

Accepted 16/6/2016

\begin{abstract}
Background - A multitude of endoscopic findings post-gastric bypass procedures have been previously reported in the literature, but to our knowledge, no present rules exist that could guide clinicians regarding which findings should be actively sought, once an initial finding is identified. Objective - To identify co-occurrence patterns among endoscopic findings of patients having undergone past gastric bypass procedure. Methods - Our registry involves all consecutive patients undergoing an upper endoscopic evaluation after a gastric bypass procedure. We collected information on the presence of the endoscopic findings in post-gastric bypass surgery patients. Co-occurrence evaluation involved the use of intersection, cluster and item factor analyses. Results - A total of 396 endoscopic evaluations were made on 339 patients. Most patients were female (81.1\%), with an average BMI of $31.88 \pm 6.7$ at the time of endoscopy. Esophagitis was the most common isolated finding $(35.3 \%)$. Endoscopic findings clustered around two groups, (1) the ring-related complications involving ring displacement, ring slips and gastric pouch, while (2) stenosis-related findings involved dilation and stenosis $(P<0.01)$. Conclusion - While most endoscopic findings after gastric bypass endoscopic procedures are isolated, ring and stenosis-related clusters should be used as a set of rules by clinicians, as it might enhance their probability of finding co-occurring conditions.
\end{abstract}

HEADINGS - Bariatric surgery. Gastric bypass, adverse effects. Gastrointestinal endoscopy. Treatment outcome.

\section{INTRODUCTION}

Bariatric procedures have long been shown to decrease the morbidity associated with morbid obesity $^{(16)}$, and also to prolong life ${ }^{(3,15)}$. While its benefits largely outweighs its short and long-term complications $^{(4,6)}$, gastrointestinal symptoms have to be closely monitored on a regular basis, with endoscopy playing an important role in the screening for potential complications. Different endoscopic post-operative findings have been described in the literature, but to the best of our knowledge no previous studies have evaluated the most common patterns of finding co-occurrence. Such studies would provide guidance on what additional endoscopic findings to anticipate once a particular post-operative finding has been encountered.

A wide range of post-operative endoscopic findings have been reported in the literature. Apart from an anastomotic stricture noted to occur in approximately $52.6 \%$ of cases, the remaining occurs in two to ten percent of all patients, including marginal ulcers, unraveled, non-absorbable sutures causing obstruction in the functioning of the upper gastrointestinal tract, gastrogastric fistulae, band erosion, staple band dehiscence, stenosis, and hiatus hernia ${ }^{(8,13,21,25,26)}$. In this multitude of possible findings, a normal gastric endoscopy has been consistently reported as the most common post-operative endoscopic finding in these patients $^{(8,10,14,22)}$. Despite these findings, to our knowledge none of these previous studies has reported co-occurring patterns.

In face of this gap in the literature, the objective of this study was to conduct a co-occurrence analysis to investigate the most common finding associations in the endoscopic evaluation of post-gastric bypass surgery patients.

Kaiser Hospital Dia, São José do Rio Preto, SP, Brasil; ${ }^{2}$ Grupo Brasileiro de Endoscopia Bariátrica; ${ }^{3}$ Gastro Obeso Center, São Paulo, SP, Brasil; ${ }^{4}$ Universidade Federal de Pernambuco, Recife, PE, Brasil.

Correspondence: Luiz Gustavo de Quadros. Kaiser Hospital Dia, Departamento de Endoscopia e Cirurgia Bariátrica. Rua XV de Novembro, 3975 Redentora - CEP: 15015-110 - São José do Rio Preto, SP, Brasil. E-mail: gustavo_quadros@hotmail.com 


\section{METHODS}

\section{Study design}

This is a cross-sectional, registry-based study to evaluate the co-occurrence of endoscopic findings in post-gastric bypass procedures. This study is described in accordance with the STROBE (STrengthening the Reporting of OBservational studies in Epidemiology) guidelines ${ }^{(23)}$. A total of 396 observations on 339 consecutive patients were part of this analysis.

\section{Ethics}

Our study was approved by the Institutional Review Board associated with our institution. Given that the study was part of a registry, all records were de-identified, ultimately reducing the risk of a privacy breach.

\section{Setting}

Data were collected at the Bariatric Service within the Kaiser Clinic and Hospital, São José do Rio Preto, Brazil. Endoscopic procedures occurred between January 2014 and July of 2015.

\section{Participants}

Inclusion criteria involved consecutive patients having previously undergone a gastric bypass procedure provided at the Kaiser Clinic and Hospital, and undergoing a diagnostic endoscopy secondary to a symptom. Patients below 18 years of age were excluded.

\section{Variables}

Our main variables of interest were age, gender, time since bypass procedure, body mass index at surgery (weight in kilogram over the square of height in meters), body mass index at the time of the endoscopy procedure, as well as those describing endoscopic findings: Presence of a gastric pouch, if this pouch exceeded four centimeters or was associated with any wall lesion, presence of an anastomosis, presence of a fistula connecting the gastric cavity to any other region, ring displacement, esophagitis, Helicobacter pylori, intruded suture, intruded rings, presence of a marginal ulcer, visible staples, dilation and any type of stenosis.

\section{Statistical methods}

Our exploratory analysis started by evaluating distributions, frequencies and percentages for each of the numeric and categorical variables. Categorical variables were evaluated for near-zero variation ${ }^{(12)}$. Crude intersection was evaluated for selected variables to investigate isolated and paired occurrences. Extensive graphical displays were used for both univariate analysis and bivariate associations, accompanied by broader tests such as Maximal Information Coefficient $^{(20)}$ and Nonnegative Matrix Factorization ${ }^{(17)}$ algorithms for numeric variables. Missing data were explored using a combination of graphical displays involving univariate, bivariate and multivariate methods. Imputation was performed using a k-nearest neighbors algorithm $(\mathrm{n}=5)^{(18)}$.

We then performed an analysis using unsupervised trees of hierarchical clustering ${ }^{(9)}$ to identify the most common associations and hierarchical patterns among counts of the following variables: pouch, anastomosis, fistula, intruded rings, esophagitis, pouch accompanied by a gastric lesion of any nature, intruded suture, ring slip, marginal ulcer, visible staples, dilation and stenosis. Isolated variables were also analyzed using item factor analysis, which allows for the latent variable patterns among dichotomous variables. All analyses were performed using the $\mathrm{R}$ language ${ }^{(19)}$ and the following packages: ggplot $2^{(24)}$, rmarkdown ${ }^{(2)}$.

\section{RESULTS}

\section{Participants}

Most of our patients were females in their late 30 s, with those having higher BMI being younger. The endoscopic exam occurred at an average of 3.6 years since the original bypass procedure, with patients having lost an average of $10 \mathrm{BMI}$ points at that time. The most common finding was esophagitis, and the least common, an intruded ring. The greater time since bypass procedure as well as the presence of ring, gastric pouch dimensions and prevalence of pouch greater than $4 \mathrm{~cm}$ were significantly associated with high BMI (Table 1).

When evaluating the crude intersection across endoscopic findings (Figure 1), we observed that most findings were isolated (straight line), the most intersecting findings including dilation and stenosis, followed by intruded sutures and esophagitis, both represented by the line with circles. As expected, esophagitis was not only the most common finding but also the most common finding associated with other findings.

When evaluating lesion co-occurrence, we observed two large clusters, one related to ring-related complications and another related to stenosis-related complications. Both were demonstrated by the tree branches as well as through the aggregated color patches. Ring-related findings involved ring displacement, ring slips, pouch-associated lesions, and any other complications associated with rings. The second cluster involved dilation and stenosis (Figure 2).

Given that the previous analysis assumes a normal distribution, we sought to confirm this association through an item factor analysis, again obtaining a similar result in relation to the ring-related cluster, grouping, ring displacement, ring slips, intruded rings. A second group was found related to stenosis involving findings such as stenosis, dilation and marginal ulcer (Table 2).

A graphical display of the factor analysis and a plot displaying factor analysis results are demonstrated on (Figure 3 and 4). 
TABLE 1. Patient sample characteristics by body mass index

\begin{tabular}{|c|c|c|c|c|}
\hline Variable & Total (396) & $\begin{array}{l}\text { Low BMI } \\
\text { (198) }\end{array}$ & $\begin{array}{l}\text { High BMI } \\
\text { (197) }\end{array}$ & $P$ \\
\hline Age & $\begin{array}{c}38.77 \\
( \pm 11.02)\end{array}$ & $\begin{array}{c}40.39 \\
( \pm 12.04)\end{array}$ & $\begin{array}{c}37.15 \\
( \pm 9.68)\end{array}$ & 0.003 \\
\hline Female & $\begin{array}{c}321 \\
(81.1 \%)\end{array}$ & $\begin{array}{c}174 \\
(87.9 \%)\end{array}$ & $\begin{array}{c}146 \\
(74.1 \%)\end{array}$ & $<0.001$ \\
\hline $\begin{array}{l}\text { Time since bypass } \\
\text { procedure }\end{array}$ & $\begin{array}{c}3.66 \\
( \pm 3.62)\end{array}$ & $\begin{array}{c}3.24 \\
( \pm 3.29)\end{array}$ & $\begin{array}{c}4.07 \\
( \pm 3.88)\end{array}$ & 0.023 \\
\hline BMI at endoscopy & $\begin{array}{c}31.88 \\
( \pm 6.79)\end{array}$ & $\begin{array}{l}29.34 \\
( \pm 4.78)\end{array}$ & $\begin{array}{l}34.43 \\
( \pm 7.53)\end{array}$ & $<0.001$ \\
\hline Ring & $\begin{array}{c}64 \\
(16.2 \%)\end{array}$ & $\begin{array}{c}22 \\
(11.1 \%)\end{array}$ & $\begin{array}{c}41 \\
(20.8 \%)\end{array}$ & 0.013 \\
\hline Esophagitis & & & & 0.155 \\
\hline $\begin{array}{l}\text { Barrett's } \\
\text { esophagus }\end{array}$ & $\begin{array}{c}9 \\
(2.3 \%)\end{array}$ & $\begin{array}{c}2 \\
(1 \%)\end{array}$ & $\begin{array}{c}7 \\
(3.6 \%)\end{array}$ & \\
\hline $\begin{array}{l}\text { Esophagitis non } \\
\text { erosive }\end{array}$ & $\begin{array}{c}44 \\
(11.1 \%)\end{array}$ & $\begin{array}{c}22 \\
(11.1 \%)\end{array}$ & $\begin{array}{c}22 \\
(11.2 \%)\end{array}$ & \\
\hline Grade A & $\begin{array}{c}33 \\
(8.3 \%)\end{array}$ & $\begin{array}{c}16 \\
(8.1 \%)\end{array}$ & $\begin{array}{c}17 \\
(8.6 \%)\end{array}$ & \\
\hline Grade B & $\begin{array}{c}31 \\
(7.8 \%)\end{array}$ & $\begin{array}{c}16 \\
(8.1 \%)\end{array}$ & $\begin{array}{c}15 \\
(7.6 \%)\end{array}$ & \\
\hline Grade C & $\begin{array}{c}8 \\
(2 \%)\end{array}$ & $\begin{array}{c}7 \\
(3.5 \%)\end{array}$ & $\begin{array}{c}1 \\
(0.5 \%)\end{array}$ & \\
\hline Grade D & $\stackrel{2}{2} \%)$ & $\begin{array}{c}2 \\
(1 \%)\end{array}$ & $\begin{array}{c}0 \\
(0 \%)\end{array}$ & \\
\hline Pouch $(\mathrm{cm})$ & $\begin{array}{c}4.57 \\
( \pm 1.24)\end{array}$ & $\begin{array}{c}4.42 \\
( \pm 1.18)\end{array}$ & $\begin{array}{c}4.7 \\
( \pm 1.27)\end{array}$ & 0.025 \\
\hline $\begin{array}{l}\text { Pouch greater than } \\
4 \mathrm{~cm}\end{array}$ & $\begin{array}{c}9 \\
(2.3 \%)\end{array}$ & $\begin{array}{c}1 \\
(0.5 \%)\end{array}$ & $\begin{array}{c}8 \\
(4.1 \%)\end{array}$ & 0.042 \\
\hline Pouch lesion & $\begin{array}{c}18 \\
(4.5 \%)\end{array}$ & $\begin{array}{c}8 \\
(4 \%)\end{array}$ & $\begin{array}{l}10 \\
(5.1 \%)\end{array}$ & 0.801 \\
\hline Anastomosis (mm) & & & & 0.202 \\
\hline 01 to 5 & $\begin{array}{c}21 \\
(5.3 \%)\end{array}$ & $\begin{array}{l}9 \\
(4.5 \%)\end{array}$ & $\begin{array}{c}12 \\
(6.1 \%)\end{array}$ & \\
\hline 06 to 10 & $\begin{array}{c}74 \\
(18.7 \%)\end{array}$ & $\begin{array}{c}44 \\
(22.2 \%)\end{array}$ & $\begin{array}{c}30 \\
(15.2 \%)\end{array}$ & \\
\hline 11 to 15 & $\begin{array}{c}158 \\
(39.9 \%)\end{array}$ & $\begin{array}{c}83 \\
(41.9 \%)\end{array}$ & $\begin{array}{c}75 \\
(38.1 \%)\end{array}$ & \\
\hline 16 to 20 & $\begin{array}{c}104 \\
(26.3 \%)\end{array}$ & $\begin{array}{c}45 \\
(22.7 \%)\end{array}$ & $\begin{array}{c}58 \\
(29.4 \%)\end{array}$ & \\
\hline 21 to 30 & $\begin{array}{c}35 \\
(8.8 \%)\end{array}$ & $\begin{array}{c}14 \\
(7.1 \%)\end{array}$ & $\begin{array}{c}21 \\
(10.7 \%)\end{array}$ & \\
\hline 31 to 40 & $\begin{array}{l}2 \\
(0.5 \%)\end{array}$ & $\begin{array}{c}2 \\
(1 \%)\end{array}$ & $\begin{array}{c}0 \\
(0 \%)\end{array}$ & \\
\hline 40 to 100 & $\begin{array}{c}2 \\
(0.5 \%)\end{array}$ & $\begin{array}{c}1 \\
(0.5 \%)\end{array}$ & $\begin{array}{c}1 \\
(0.5 \%)\end{array}$ & \\
\hline Intruded suture & $\begin{array}{c}73 \\
(18.4 \%)\end{array}$ & $\begin{array}{c}34 \\
(17.2 \%)\end{array}$ & $\begin{array}{c}38 \\
(19.3 \%)\end{array}$ & 0.678 \\
\hline Intruded ring & $\begin{array}{c}4 \\
(1 \%)\end{array}$ & $\begin{array}{c}2 \\
(1 \%)\end{array}$ & $\begin{array}{c}2 \\
(1 \%)\end{array}$ & 1 \\
\hline Ring slip & $\begin{array}{c}35 \\
(8.8 \%)\end{array}$ & $\begin{array}{c}13 \\
(6.6 \%)\end{array}$ & $\begin{array}{c}22 \\
(11.2 \%)\end{array}$ & 0.152 \\
\hline Marginal ulcer & $\begin{array}{c}24 \\
(6.1 \%)\end{array}$ & $\begin{array}{c}15 \\
(7.6 \%)\end{array}$ & $\begin{array}{c}9 \\
(4.6 \%)\end{array}$ & 0.298 \\
\hline Visible staples & $\begin{array}{c}76 \\
(19.2 \%)\end{array}$ & $\begin{array}{c}38 \\
(19.2 \%)\end{array}$ & $\begin{array}{c}38 \\
(19.3 \%)\end{array}$ & 1 \\
\hline Stenosis & $\begin{array}{c}37 \\
(9.3 \%)\end{array}$ & $\begin{array}{c}18 \\
(9.1 \%)\end{array}$ & $\begin{array}{c}19 \\
(9.6 \%)\end{array}$ & 0.987 \\
\hline Dilation & $\begin{array}{c}37 \\
(9.3 \%)\end{array}$ & $\begin{array}{c}18 \\
(9.1 \%)\end{array}$ & $\begin{array}{c}19 \\
(9.6 \%)\end{array}$ & 0.974 \\
\hline Fistula & $\begin{array}{c}5 \\
(1.3 \%)\end{array}$ & $\begin{array}{c}2 \\
(1 \%)\end{array}$ & $\begin{array}{c}3 \\
(1.5 \%)\end{array}$ & 0.995 \\
\hline H. pylori & $\begin{array}{c}11 \\
(2.8 \%) \\
\end{array}$ & $\begin{array}{c}5 \\
(2.5 \%) \\
\end{array}$ & $\begin{array}{c}6 \\
(3 \%) \\
\end{array}$ & 0.993 \\
\hline
\end{tabular}

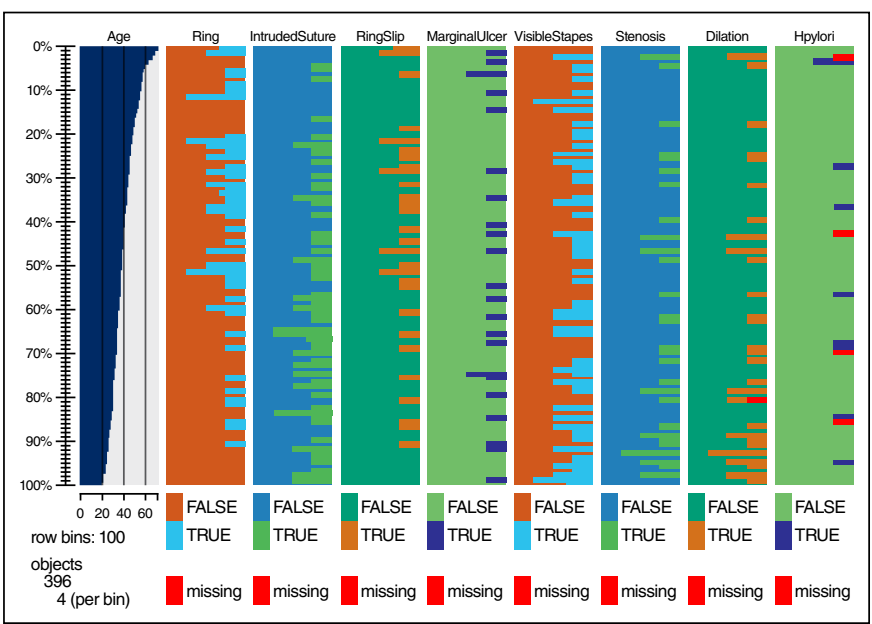

FIGURE 1. Patient sample characteristics by age

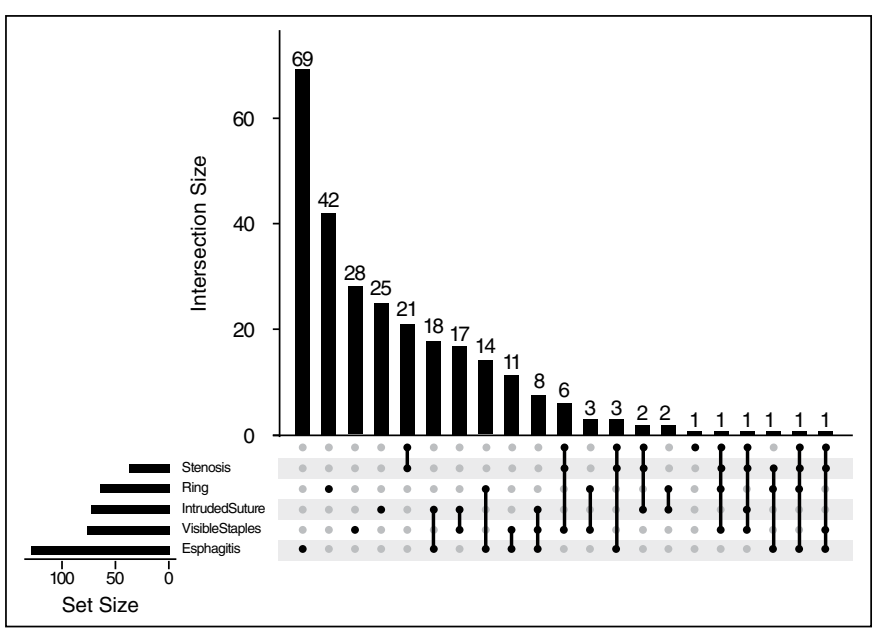

FIGURE 2. Intersection graphic across different findings

TABLE 2. Factor loadings for item factor analysis

\begin{tabular}{lcc}
\hline Variable & Ring cluster & Stenosis cluster \\
\hline Intruded ring & 0.9155471 & 0.1593664 \\
Ring & 0.8756112 & 0.0555071 \\
Pouch greater than 4cm & 0.76082 & 0.2225955 \\
Ring slip & 0.7594867 & 0.0785865 \\
Visible staples & 0.7384883 & 0.041114 \\
Intruded suture & 0.7063942 & 0.1252824 \\
Pouch (cm) & 0.4767567 & 0.117672 \\
Esophagitis & 0.4181584 & 0.123986 \\
Marginal ulcer & 0.3791405 & 0.8419599 \\
Dilation & 0.2961818 & 0.9504888 \\
Stenosis & 0.2642788 & 0.955542 \\
Pouch lesion & 0.1955905 & 0.086231 \\
Anastomosis & 0.0959897 & 0.3534908 \\
H. pylori & 0.0770348 & 0.5638843 \\
Fistula & 0.0747534 & 0.3172821 \\
\hline
\end{tabular}




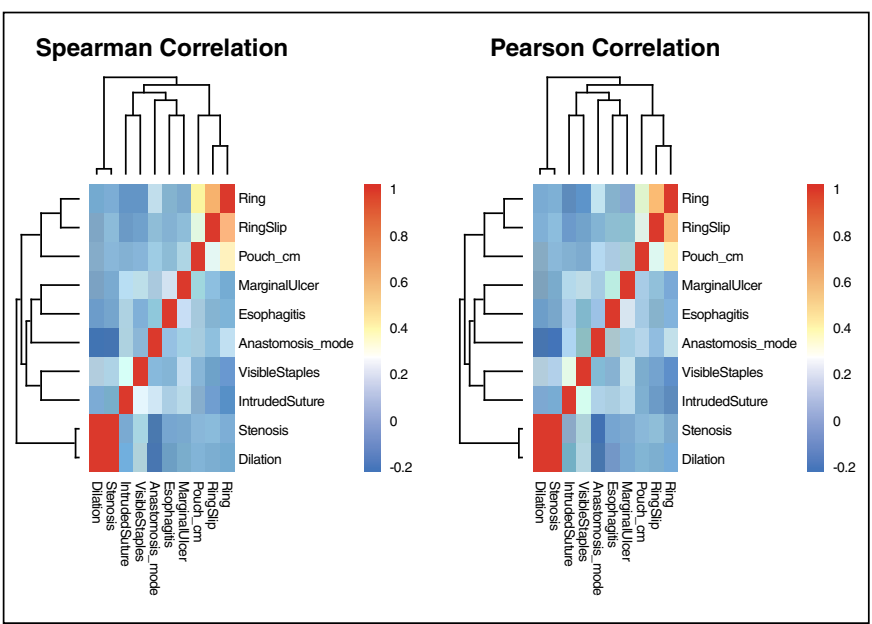

FIGURE 3. Heatmap displaying the association across counts of different endoscopic findings

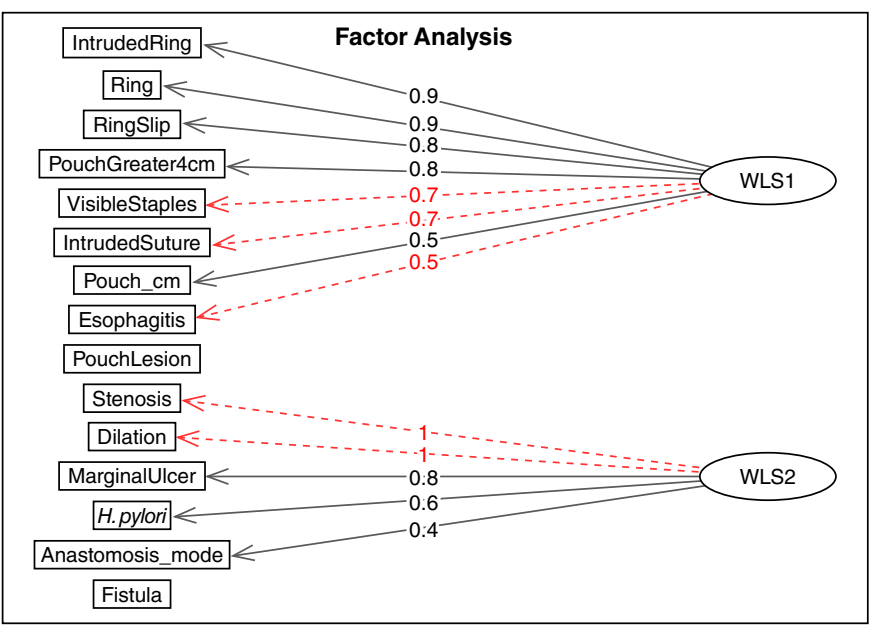

FIGURE 4. Plot displaying factor analysis results

\section{DISCUSSION}

To the best of our knowledge, this is the first study evaluating co-occurrence patterns for long-term endoscopic findings in patients having undergone gastric bypass procedures. We found that findings tend to cluster across two large groups, the first associated with ring-related complications, and the second associated to stenosis-related complications. In addition, esophagitis was not only the most common isolated finding but, likely as a consequence, also the most common finding associated with other lesions.

Variable rates of endoscopic findings have been observed in different studies after bariatric surgery. In one series investigating ways of managing postoperative symptoms, the authors reported the following frequencies for different findings; normal post-surgical anatomy (43\%), marginal ulcer $(27 \%)$, stomal stenosis $(19 \%$, including $10 \%$ with a concomitant marginal ulcer), and staple-line dehiscence (eight patients, $16 \%$, including $2 \%$ with a marginal ulcer) (13). A recent study presented stenosis as the main finding in $35.5 \%$ of patients, with marginal ulcer being the second most common finding $(n=9)^{(7)}$. In another series associating symptoms to specific findings, reports included normal surgical anatomy $(31.6 \%)$, anastomotic stricture $(52.6 \%)$, marginal ulcer (15.8\%), unraveled non-absorbable sutures causing functional obstruction (4\%) and gastro-gastric fistula $(2.6 \%)^{(10)}$. This series also reported an unusual finding involving a completely obstructed anastomotic stricture ${ }^{(10)}$. In one last case series, a group evaluating complications of various therapies noted stomal ulceration and stenosis in, respectively, $12.5 \%$ and $12 \%$ of 191 patients who underwent gastric bypass. Only $3 \%$ had both complications simultaneously ${ }^{(1)}$. The mechanism underlying the occurrence of these complications is poorly understood but has been posited to depend on physician skill ${ }^{(5)}$. The marginal ulcer is most probably related to the accumulation and non-use of acid gastric fluids after the surgical procedure. These findings are of clinical significance as a series associating symptoms with the previously mentioned findings has demonstrated that abdominal pain was the most common symptom $(53 \%)$, being more frequent among patients with a normal endoscopy than among those with an abnormal endoscopy $(P=0.04)$. Stomal stenosis was present in $39 \%$ of patients with nausea, vomiting, or dysphagia, while it was also not present in any patient without these symptoms $(P=0.001)^{(10)}$.

Although analyses involving the co-occurrence of patient factors in gastric bypass surgery is significant in providing specialists with a set of rules to actively search for additional findings, to our knowledge no previous study has evaluated co-occurrence patterns of endoscopic findings. Instead, cluster analysis have been used as a mechanism to evaluate factors associated with specific clinical outcomes. For example, a cluster analysis relating surgical skill and complications after bariatric surgery has found that greater surgical skill is frequently associated with better surgical outcomes $^{(5)}$. In another study, obese patients without mental disorders were found to be associated with better outcomes than those with psychiatric disorders ${ }^{(11)}$. While both of these studies have had important clinical implications, we would argue that clustering methods should be more often used in the evaluation of the co-occurrence of symptoms and signs, as clusters can provide a set of rules of the type "if a given finding is encountered, then a second related finding should be actively searched."

Despite being the first study evaluating the co-occurrence of endoscopic findings, our study does have limitations. First, our data were collected as part of a registry, rather than as a specific study envisioning the present research question. However, since we follow a standard reporting protocol with pre-defined categories for all of our endoscopic reports, data entry error and bias should have been minimized. In addition, given that our protocol did not originally foresee a research study, we would argue that our results are more likely to represent a "real-world" practice. Second, among our analytical methods, we have made use of tests such as the 
Pearson Correlation test where variables are assumed to be normally distributed, while our variables represented counts. Although this might appear as an assumption violation, our findings were consistent across all tests, ultimately validating the existence of two large clusters of endoscopic findings. Third, all exams were performed by a single specialist, our study not having a companion reliability validation. Fourth, our results are applicable as long as the patients are symptomatic, as this is one of our inclusion criterion. This study characteristic should be taken into account when attempting to introduce our findings into clinical practice.

In conclusion, our study has implications for future practice in that trainees and practitioners finding one of the components within a cluster should actively search for other components given their high association. Future studies should validate these findings across different clinical practices as well as with specialists at different expertise levels.

\section{Authors' contributions}

Quadros LG: conception and design, analysis and interpretation, drafting of the manuscript, final approval of the manuscript. Kaiser Junior RL: analysis and interpretation, drafting of the manuscript. Galvão Neto MP: analysis and interpretation, reviewing, final approval of the manuscript. Campos JM: analysis and interpretation, reviewing, final approval of the manuscript. Santana MF: conception, interpretation and drafting of the manuscript. Ferraz AAB: reviewing.

Quadros LG, Kaiser Junior RL, Galvão Neto MP, Campos JM, Santana MF, Ferraz AAB. Achados endoscópicos no pós-operatório tardio após bypass gástrico: análise de co-ocorrência. Arq Gastroenterol. 2016,53(4):273-7.

RESUMO - Contexto - Uma grande quantidade de achados endoscópicos após procedimentos de bypass pós-gástricos foram previamente relatados na literatura, mas, que seja de nosso conhecimento, não existem regras atuais que poderiam orientar os médicos sobre quais achados devem procurar uma vez que um achado inicial é identificado. Objetivo - Identificar padrões de co-ocorrência entre os achados endoscópicos de pacientes submetidos ao procedimento de bypass gástrico no passado. Métodos - O nosso registo envolve pacientes consecutivos submetidos a uma avaliação endoscópica alta após um procedimento de bypass gástrico. Foram colhidas informações sobre a presença de achados endoscópicos após cirúrgica de bypass gástrico à Y de Roux com ou sem anel. Avaliação de co-ocorrência envolveu o uso de cruzamento, agrupamento e fator de produto de análise Resultados - Um total de 396 avaliações endoscópicas foram realizadas em 339 pacientes. A maioria dos pacientes eram do sexo feminino (81,1\%), com IMC médio de 31,88 $\pm 6,7$ no momento da endoscopia. Esofagite foi o achado isolado mais comum (35,3\%). Achados endoscópicos agrupados em torno de dois grupos, as complicações relacionadas ao anel envolveram deslocamento anel, deslizamentos anel e bolsa gástrica e relacionadas a estenoses envolveram dilatação e estenose $(P<0,01)$. Conclusão - Enquanto a maioria dos achados endoscópicos após procedimentos de bypass gástrico são isolados, agrupamento relacionado a anel e estenose poderiam ser usados como um conjunto de regras para médicos, uma vez que pode melhorar a sua probabilidade de ser encontrando em condições co-ocorrentes.

DESCRITORES - Cirurgia bariátrica. Derivação gástrica, efeitos adversos. Endoscopia gastrointestinal. Resultado do tratamento.

\section{REFERENCES}

1. Aj S, Hj S, Jm K, Km E, L W. Stomal complications of gastric bypass: Incidence and outcome of therapy. Am J Gastroenterol. 1992;87:1165-9.

2. Allaire J, Cheng J, Xie Y, McPherson J, Chang W, Allen J, et al. Rmarkdown: Dynamic documents for R. 2015. Available from: http://CRAN.R-project.org/ package $=$ rmarkdown

3. Arterburn DE, Olsen MK, Smith VA, Livingston EH, Van Scoyoc L, Yancy WS Jr, Eid G, Weidenbacher H, Maciejewski ML. Association between bariatric surgery and long-term survival. JAMA. 2015;313:62-70.

4. Balsiger BM, Luque de Leon E, Sarr MG. Surgical treatment of obesity: Who is an appropriate candidate? Mayo Clin Proc. 1997;72:551-7; quiz 558.

5. Birkmeyer JD, Finks JF, O’Reilly A, Oerline M, Carlin AM, Nunn AR, Dimick J, Banerjee M, Birkmeyer NJ. Surgical skill and complication rates after bariatric surgery. N Engl J Med. 2013;369:1434-42.

6. Brethauer SA, Chand B, Schauer PR. Risks and benefits of bariatric surgery: Current evidence. Cleve Clin J Med. 2006;73:993-1007.

7. Czeczko LEA, Cruz MA, Klostermann FC, Czeczko NG, Nassif PAN, Czeczko AEA. Correlation between pre and postoperative upper digestive endoscopy in patients who underwent roux-en-y gastrojejunal bypass. Arq Bras Cir Dig. 2016;29:33-7.

8. Flores-Gama F, Puente-Espel J, Bahena-Aponte J, Moreno-Portillo M, Rojano-Rodríguez M. [Endoscopy and bariatric surgery. a new challenge?]. Cir Cir. 2007;75:425-28.

9. Galili T. Dendextend: An r package for visualizing, adjusting, and comparing trees of hierarchical clustering. Bioinformatics. 2015. Available from: http://dx.doi. org/10.1093/bioinformatics/btv428

10. Huang CS, Forse RA, Jacobson BC, Farraye FA. Endoscopic findings and their clinical correlations in patients with symptoms after gastric bypass surgery. Gastrointest Endosc. 2003;58:859-66.

11. Kinzl JF, Schrattenecker M, Traweger C, Mattesich M, Fiala M, Biebl W. Psychosocial predictors of weight loss after bariatric surgery. Obes Surg. 2006;16:1609-14.

12. Kuhn M, Johnson K. Applied Predictive Modeling. 2013. Springer, NY.

13. Lee JK, Van Dam J, Morton JM, Curet M, Banerjee S. Endoscopy is accurate, safe, and effective in the assessment and management of complications following gastric bypass surgery. Am J Gastroenterol. 2009;104:575-82; quiz 583.
14. Marano BJ Jr. Endoscopy after roux-en-y gastric bypass: A community hospital experience. Obes Surg. 2005;15:342-45.

15. Marsk R, Näslund E, Freedman J, Tynelius P, Rasmussen F. Bariatric surgery reduces mortality in swedish men. Br J Surg. 2010;97:877-83.

16. Morgan DJR, Ho KM, Armstrong J, Litton E. Long-term clinical outcomes and health care utilization after bariatric surgery: A population-based study. Ann Surg. 2015;262:86-92.

17. Paatero P, Tapper U. Positive matrix factorization: A non-negative factor model with optimal utilization of error estimates of data values. Environmetrics. 1994;5:111-26.

18. Prantner B. Visualization of imputed values using the R-package VIM. 2011.

19. R Core Team. R: A language and environment for statistical computing. Vienna, Austria: R Foundation for Statistical Computing; 2015. Available from: http:// www.R-project.org/

20. Reshef DN, Reshef YA, Finucane HK, Grossman SR, McVean G, Turnbaugh PJ, et al. Detecting novel associations in large data sets. Science. 201;334:1518-24.

21. Spinosa SR, Valezi AC. Endoscopic findings of asymptomatic patients one year after roux-en-y gastric bypass for treatment of obesity. Obes Surg. 2013;23:1431-35.

22. Subhani M, Rizvon K, Mustacchia P. Endoscopic evaluation of symptomatic patients following bariatric surgery: A literature review. Diagn Ther Endosc. 2012;2012:753472.

23. Von Elm E, Altman DG, Egger M, Pocock SJ, Gøtzsche PC, Vandenbroucke JP, et al. The strengthening the reporting of observational studies in epidemiology (STROBE) statement: Guidelines for reporting observational studies. Prev Med 2007;45:247-51.

24. Wickham H. Ggplot2: Elegant graphics for data analysis. Springer New York; 2009. Available from: http://had.co.nz/ggplot2/book

25. Wilson JA, Romagnuolo J, Byrne TK, Morgan K, Wilson FA. Predictors of endoscopic findings after roux-en-y gastric bypass. Am J Gastroenterol. 2006;101:2194-99.

26. Yang C-S, Lee WJ, Wang H-H, Huang S-P, Lin J-T, Wu M-S. Spectrum of endoscopic findings and therapy in patients with upper gastrointestinal symptoms after laparoscopic bariatric surgery. Obes Surg. 2006;16:1232-37. 